\title{
The Effect of Condensed Tannin and Saponin in Reducing Methane Produced during Rumen Digestion of Agricultural Byproducts
}

\author{
Widiawati Y, Puastuti W \\ Indonesian Research Institute for Animal Production \\ PO Box 221 Bogor 16002, West Java, Indonesia \\ yeni_widiawati14@yahoo.com
}

\begin{abstract}
Saponin and tannin have been considered as chemical compounds that can reduce methane enteric fermentation. The magnitude of the effect of the compounds on reducing methane are various depend on the levels and sources of the compounds. Some local plants that contained high condensed tannin and saponin are Acacia leaves and Lerak fruit. Feed available for ruminants mostly come from agricultural and plantation byproducts that characterized by high NDF content and low digestibility that promote methane production. The aim of study was to investigate the effect of saponin and condensed tannin extracts in reducing methane resulted during rumen fermentation of rice straw, maize straw, sugarcane-top and palm oil leaves. The in vitro method was used to evaluate 24 feedtuffs that were incubated for 48 hours. Saponin and condensed tannin extracts were added individually at the level of $2.5 \%$ of DM for each feed sample. Variables measured were chemical composition of feeds, total gas and methane production. Total cumulative gas of sugarcane-top and palm oil leaves fermentation increased when saponin $(\mathrm{P}<0.01)$ or condensed tannin $(\mathrm{P}<0.05)$ was added, but saponin or condensed tannin had no effect on rice straw and maize straw. Due to saponin and condensed tannin, the proportion of methane to total gas was reduced by 16.41 and $17.36 \%$ for sugarcane-top, 4.75 and $11.20 \%$ for palm oil leaves, 4.26 and $6.38 \%$ for maize straw and 11.68 and $12.98 \%$ for rice straw, respectively. The conclusions are that the two agents can reduce methane produced during the rumen fermentation of feedstuffs, and the effect of saponin and condensed tannin was different among the feedstuffs investigated, the condensed tannin has bigger effect on reducing methane production than saponin.
\end{abstract}

Key Words: Saponin, Condensed Tannin, Methane, Agricultural Byproducts

\section{INTRODUCTION}

Methane gives the strongest effect of greenhouse gas than other gasses. The effect of methane was 20-50 times higher than carbondioxide (Beauchemin \& McGinn 2005). Methane emitted from livestock comes from feed digestion in the rumen as enteric fermentation. The amount of methane emitted from enteric fermentation is influenced by the fibre content of the feed, in particular NDF content. Increasing in NDF content of feed would increases methane produced during the fermentation (Kulivand \& Kafilzadeh 2015). The main feed used in ruminant production in most tropical regions are roughages characterized by high in fibre content. Nowdays, ruminants consume agricultural and plantation byproducts as the main components of their diets. The feeds are characterized by high NDF content and low digestibility (Maryono \& Khrisna 2009). Therefore, it is expected that they will produce high methane when digested in the rumen.

Owing to this concern on global warming, many scientists, particularly in livestock production system, conducted many studies in order to identify techniques to mitigate methane emissions. Some techniques are through feed additives (Thalib 2004; Widiawati et al. 2013; Thalib 2008; Thalib et al. 2010; 2011), supplementation of low quality feed by legumes or concentrate feed (Widiawati 2004; Pramote et al. 2006), formulating and providing balance diet (Widiawati 2013; Liang et al. 2013). Decreased methane emitted from enteric fermentation was reported to up to $12.2-16.3 \%$ when Complete Rumen 
Modifier (CRM) was added to sheep diet. A complete feed consisted of legume leaves and agricultural byproducts was reported to reduce methane emission from enteric fermentation by $10-15 \%$ (Widiawati et al. 2013).

Two plant secondary compounds proven to decrease methane production are saponin and tannin (Kamra et al. 2006; Jayanegara et al. 2011). Tannin extracted from some tannin containing plants, such as chestnut, mimosa, quebracho and sumach significantly reduced methane produced from grass hay in in vitro experiment (Jayanegara et al. 2010). Tannin extracted from chestnut and sumach was hydrosable tannin, while tannin extracted from mimosa and quebracho was condensed tannin. The two types of tannin can reduce methane produced significantly (Jayanegara et al. 2011). Saponin extracted from Sapindus rarak was reported to reduce methane production up to $31 \%$ in in vitro experiment. However, the effect was not recorded in the in vivo experiment (Thalib 2004). However, when saponin was combined with Acetoanaerobium noterae, methane production decreased up to $24 \%$ when offered to sheep (Thalib et al. 2010). Moreover, the methane mitigating property of tannin and saponin in the rumen depend on the level and sources of tannin and saponin (Jayanegara et al. 2014). Two local plants as tannin and saponin sources are Acacia (Acacia sp.) and Lerak (Sapindus rarak). These plants are reported to contain high levels of tannin (22-48\%) and saponin (81.47\%), respectively (Astuti et al. 2008; Fathoni 2010). However, there is limited information on the effects of tannin and saponin on reducing methane production from agricultural and plantation byproduct based diet fermented in the rumen. Therefore, the study was aimed to investigate the effect of tannin and saponin exctracted from local sources, namely Acacia and Lerak, on reducing methane produced from agricultural and plantation byproduct based diet fermented in the rumen.

\section{MATERIAL AND METHODS}

\section{Experimental feeds and design}

\section{Feed samples}

Eight different feeds were used in this study, namely palm oil leaves (POL), palm oil leaves silage (POLS), sugarcane top (SCT), sugarcane top silage (SCTS), maize straw (MS), maize straw silage (MSS), rice straw (RS), and rice straw silage (RSS). Fresh material of the feeds were ovendried at $60^{\circ} \mathrm{C}$ for three days, grinded and kept in refrigerator before used. The nutrient contents of each feed were analyzed by the procedure of Association of Official Analytical Chemists (AOAC 1990).

\section{Saponin and tannin exctraction}

Tannin was exctracted from dry leaves of Acacia (Acacia sp.) using methanol $50 \%$ $(1: 4 \mathrm{w} / \mathrm{v})$. Tannin resulted from this method was total condensed tannin. Saponin from Lerak fruit (Sapindus rarak) was extracted using methanol 50\% (1:4 w/v) (Makkar et al.1995b). Acacia leaves and lerak fruit were dried using oven $60^{\circ} \mathrm{C}$ for three days then were grinded. Five gram of Acacia leaves meal was mixed with $20 \mathrm{ml}$ of methanol (50\%) and kept for $24 \mathrm{~h}$. The solution then was evaporated using rotary-evaporator at temperature of $40^{\circ} \mathrm{C}$, then was dried using freeze drying and kept in refrigerator before used. By using similar method, 5 gram of lerak fruit meal was added by $20 \mathrm{ml}$ methanol (50\%) then kept for $24 \mathrm{~h}$ at room temperature. 


\section{Experimental design}

The feed samples were individually evaluated for their potency to produce methane using in vitro rumen fermentation technique (Makkar et al. 1995b). Tannin and saponin were individually added at the level of $2.5 \%$ of DM to each feed sample. Purified tannin at the minimul level of $0.25 \mathrm{mg} / \mathrm{ml}$ buffer solution or equivalent with $25 \mathrm{mg} / \mathrm{g}$ of $\mathrm{DM}$ feed sample, can reduced methane produced from mixed diet of hay and concentrate (Yugianto et al. 2014). The total samples evaluated were 24 as presented in Table 1. Each feed sample was subjected to in vitro fermentation to measure methane production after $48 \mathrm{~h}$ of incubation.

Table 1. Feed samples and addition of tannin and saponin for each feed sample evaluated in the experiment

\begin{tabular}{llc|llc}
\hline \hline No. & Sample evaluated & Code & No. & Sample evaluated & Code \\
\hline 1. & Palm oil leaves & POL & 13. & Palm oil leaves-silage & POLS \\
2. & POL + tannin & POL-T & 14. & POLS + Tannin & POLS-T \\
3. & POL + saponin & POL-S & 15. & POLS + Saponin & POLS-S \\
4. & Sugarcane top & SCT & 16. & Sugarcane top-silage & SCTS \\
5. & SCT + tannin & SCT-T & 17. & SCTS + Tannin & SCTS-T \\
6. & SCT + saponin & SCT-S & 18. & SCTS + Saponin & SCTS-S \\
7. & Maize straw & MS & 19. & Maize straw-silage & MSS \\
8. & MS + tannin & MS-T & 20. & MSS + Tannin & MSS-T \\
9. & MS + saponin & MS-S & 21. & MSS + Saponin & MSS-S \\
10. & Rice straw & RS & 22. & Rice straw-silage & RSS \\
11. & RS + tannin & RS-T & 23. & RSS + Tannin & RSS-T \\
12. & RS + saponin & RS-S & 24. & RSS + Saponin & RSS-S \\
\hline
\end{tabular}

\section{Rumen fluid collection and buffer preparation}

Rumen fluid was collected from rumen cannulated Frisien Holstein cows fed twice a day with king grass and concentrate at the ratio $2: 1$. Five hundred milligrams of each feed sample inclusion of $2.5 \%$ of tannin or saponin was included in the in vitro fermentation. The in vitro solution used in the study was composed of ruminal fluid 22.6\%; buffer solution $25.1 \%$, mineral solution $12.5 \%$, reducing agent solution $2.1 \%$, and aquadest (Makkar et al. 1995a). Rumen fluid and buffer were mixed at the ratio of 1:3 and flushed with carbondioxide $\left(\mathrm{CO}_{2}\right)$ gas. Fifty $\mathrm{ml}$ of buffered rumen fluid was anaerobically dispensed into serum bottle then sealed with butyl-rubber stopper. Each sample was replicated three times and maintained in water bath at $39^{\circ} \mathrm{C}$ for $48 \mathrm{~h}$. During incubation, gas production (total and methane) were monitored at $0,6,12,18,24,30,36,42$, and $48 \mathrm{~h}$.

\section{Analysis in vitro fermentation parameters}

Total gas production was measured in each of serum bottle using a scaled glass syringe connected to three waytap attached to another scaled glass syringe. Measurement of methane gas produced followed the methods described by Tjandraatmadja (1981). The $\mathrm{DM}$ content of the feed was determined by drying to a constant weight in an oven at $105^{\circ} \mathrm{C}$ overnight. The ash in the feed sample and residue was determinded by combusting in a 
muffle furnance at $550^{\circ} \mathrm{C}$ for $6 \mathrm{~h}$. The $\mathrm{N}$ content of the feed was determined by the micro Kjeldahl method (AOAC 1990), NDF was analyzed according to Van Soest et al. (1991), gross energy (GE) was determined by using an auto bomb calorimeter. Chemical composition of the feed samples evaluated in this study are presented in Table 2.

Table 2. Chemical composition of feed samples used in the experiment.

\begin{tabular}{|c|c|c|c|c|c|c|c|c|}
\hline \multirow[t]{2}{*}{ Sample } & Ash & $\begin{array}{l}\text { Crude } \\
\text { fibre }\end{array}$ & $\begin{array}{l}\text { Crude } \\
\text { protein }\end{array}$ & $\begin{array}{c}\text { Crude } \\
\text { fat }\end{array}$ & \multirow{2}{*}{$\begin{array}{c}\mathrm{GE} \\
(\mathrm{kcal} / \mathrm{kg})\end{array}$} & NDF & $\mathrm{Ca}$ & $\mathrm{P}$ \\
\hline & \multicolumn{4}{|c|}{------------------ $\%$----------------- } & & \multicolumn{3}{|c|}{-------- \% ------- } \\
\hline Palm oil leaves & 7.64 & 53.48 & 4.70 & 1.58 & 4,138 & 72.56 & 0.46 & 0.80 \\
\hline Palm oil leaves-silage & 5.70 & 57.99 & 4.21 & 1.76 & 4,291 & 77.44 & 0.49 & 0.06 \\
\hline Sugarcane top & 10.18 & 39.78 & 5.47 & 1.83 & 3,868 & 72.62 & 0.25 & 0.11 \\
\hline Sugarcane top-silage & 10.42 & 46.69 & 5.14 & 2.12 & 3,993 & 70.42 & 0.57 & 0.08 \\
\hline Maize straw & 10.90 & 40.13 & 7.16 & 1.0 & 3,768 & 68.41 & 0.27 & 0.11 \\
\hline Maize straw-silage & 10.45 & 38.09 & 6.87 & 1.81 & 3,908 & 62.62 & 0.41 & 0.02 \\
\hline Rice straw & 20.40 & 32.45 & 5.32 & 1.01 & 3,212 & 69.03 & 0.17 & 0.10 \\
\hline Rice straw-silage & 19.65 & 38.80 & 4.99 & 1.56 & 3,446 & 70.45 & 0.26 & 0.08 \\
\hline
\end{tabular}

\section{Statistical analysis}

All treatments were conducted in triplicates. The means of each variable measured in this study were analysed by Analysis of Variance (ANOVA) using the procedures of the IBM IPSS Statistics version 20. The differences between means were compared by a least significant difference method (LSD).

\section{RESULTS AND DISCUSSION}

Among the byproducts investigated in this experiment, palm oil leaves have the lowest protein but the highest NDF contents. While maize straw contains more protein but less NDF compared to other feedstufs. These data indicated the quality of feedstufs. The NDF content of feed materials would have an effect on the rate of rumen digestion and the amount of methane produced. Many sudies showed that there was a positive corelation between NDF content of the feed materials and enteric methane production (Tavendale et al. 2005; Kulivand \& Kafilzadeh 2015). Proximate analyses showed that the ensiling process did not change the chemical compositions in particular the protein contents of the feed materials (Table 2).

The total cumulative gas after 48 hours of fermentation of sugarcane-top (116.17 ml) increased when saponin $(163.17 \mathrm{ml})(\mathrm{P}<0.01)$ or tannin $(132.50 \mathrm{ml})$ was added $(\mathrm{P}<0.05)$. However the proportion of methane to total gas was reduced by $16.41 \%$ and $17.36 \%$ when saponin or tannin was added, respectively (Figure 1). These results indicated that tannin gave more effect in reducing methane gas production than saponin. Silage of sugarcanetop did not change the total gas produced during rumen fermentation (116.17 vs 118.50 $\mathrm{ml})$. However, the processing reduced the proportion of methane to total gas from sugarcane-top by $11 \%$. Similar effect of tannin and saponin was also indicated in sugarcane-top silage. The proportion of methane to total gas was reduced by $19.18 \%$ when 
tannin was added, while addition of saponin only reduced the proportion of methane to total gas by $15.24 \%$.

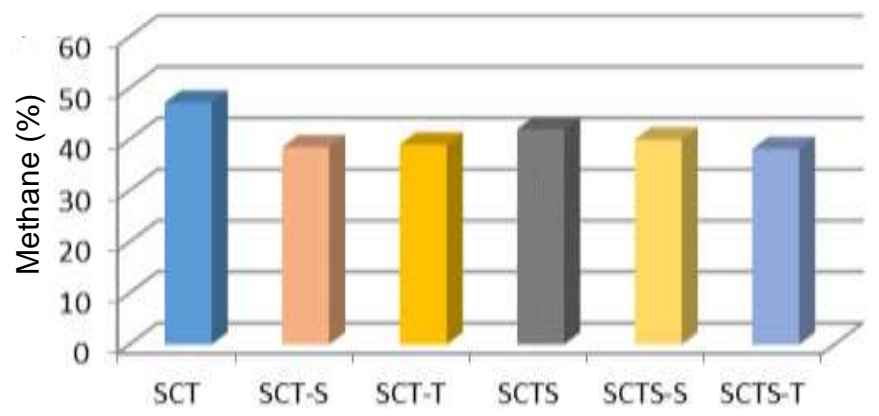

SCT: Sugarcane top; SCT-S: Sugarcane top + saponin; SCT-T: Sugarcane top + tannin; SCTS: Sugarcane top silage; SCTS-S: Sugarcane top silage + saponin; SCTS-T: Sugarcane top silage + tannin

Figure 1.Proportion of methane from total gas cumulative (\%) when sugarcane top (SCT) and sugarcane top silage (SCTS) were fermented with addition of tannin or saponin

Addition of saponin and tannin increased total gas cumulative when palm oil leaves was fermented for 48 hours, from $60.83 \mathrm{ml}$ to become 75 and $69 \mathrm{ml}$, respectively $(\mathrm{P}<0.05)$. However, the proportion of methane to total gas was reduced by $4.75 \%$ and $11.20 \%$ when saponin or tannin was added, respectively (Figure 2). Ensilage of palm oil leaves did not change the total gas produced during rumen fermentation (60.83 vs $55.33 \mathrm{ml})$. Ensilage of palm oil leaves also had no effect on methane production $(50.9 \%$ of total gas vs $50.09 \%$ of total gas). The effect of saponin and tannin was different based on the substrate/feed being fermented. When fresh palm oil leaves was fermented, tannin had more effect in reducing methane compared to saponin $(\mathrm{P}<0.05)$, while when palm oil leaves was ensilaged, the saponin and tannin had similar effect in reducing methane gas produced (4.64 and 4.19\%).

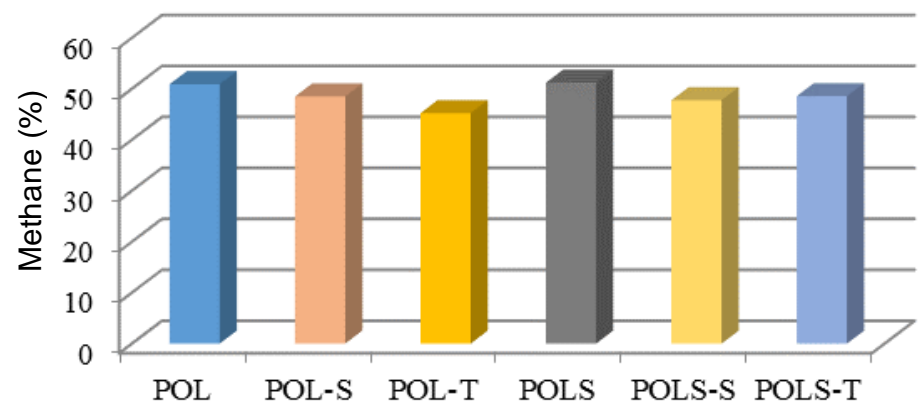

POL: Palm oil leaves; POL-S: Palm oil leaves + saponin; POL-T: Palm oil leaves + tannin; POLS: Palm oil leaves silage; POLS-S: Palm oil leaves silage +saponin; POLS-T: Palm oil leaves silage + tannin

Figure 2.Proportion of methane from total gas cumulative (\%) when palm oil leaves (POL) and palm oil leaves silage (POLS) were fermented with addition of tannin or saponin

There were no effect of additional saponin and tannin on total gas cumulative when maize straw was fermented (98.83 vs 99.33 vs $94.00 \mathrm{ml})$. The effect of saponin and tannin was very small as shown by the low reduction of methane produced (4.26 and $6.38 \%$ ) (Figure 3). Ensilage of maize straw increased total gas produced up to $106.17 \mathrm{ml}$ compared to non-ensilage $(98.83 \mathrm{ml})(\mathrm{P}<0.05)$, but has no effect on the proportion of methane gas from the total gas cumulative. Additional saponin and tannin on maize straw silage 
reduced the proportion of methane gas produced by 8.51 and $12.77 \%$ respectively. The results showed that saponin dan tannin have larger effects in reducing methane production when the maize straw was ensilaged than when as fresh maize straw.

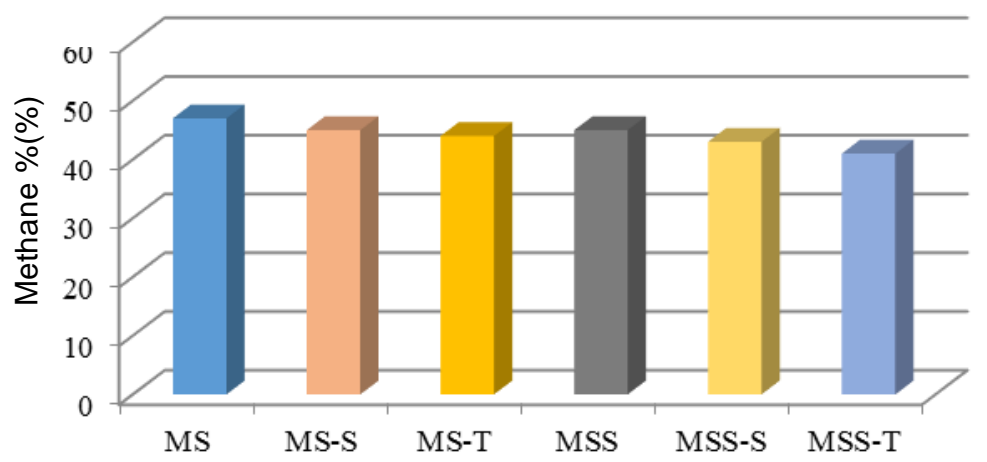

MS: Maize straw; MS-S: Maize straw + saponin; MS-TL: Maize straw + tannin; MSS: Maize straw silage; MSS-S: Maize straw silage + saponin; MSS-T: Maize straw silage + tannin

Figure 3.Proportion of methane from total gas cumulative (\%) when maize straw (MS) and maize straw silage (MSS) were fermented with addition of tannin or saponin

There were no effect of additional saponin and tannin on total gas cumulative of rice straw (73.67 vs 83.83 vs $79.17 \mathrm{ml}$ ). The proportion of methane to total gas cumulative was also similar for RS (48.68\%), RS-S (46.81\%), and RS-T (46.12\%). The reduction of proportion methane gas per total gas cumulative was acounted for 11.68 and $12.98 \%$ when saponin and tannin was added. Ensiling process reduced total gas cumulative up to 66.33 $\mathrm{ml}$, as well as the proportion of methane to total gas by 5.66\%. The reduction of proportion methane to total gas was increased up to $9.43 \%$ and $13.21 \%$ when rice straw silage was added by saponin and tannin, respectively (Figure 4).

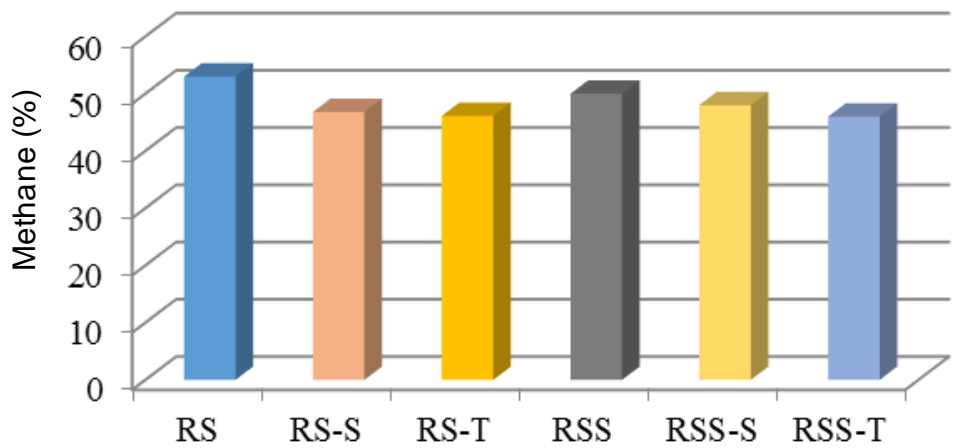

RS: Rice straw; RS-S: Rice straw + saponin; RS-T: Rice straw + tannin; RSS: Rice straw silage; RSS-S: Rice straw silage + saponin; RSS-T: Rice straw silage + tannin

Figure 4.Proportion of methane from total gas cumulative (\%) when rice straw (RS) and rice straw silage (RSS) were fermented with addition of tannin or saponin

Among the four feedtuffs investigated, total gas produced during the 48 hours of incubation was different $(\mathrm{P}<0.05)$. The gas produced from sugarcane-top fermentation was the highest, while total gas produced from palm oil leaves was the lowest. The gas produced during the rumen digestion of feeds can indicate the amount of substrate being digested. The amount of gas produced linearly with the amount of dry matter digested (Hart et al. 2009). The two feeds contain similar amount of NDF but sugarcane-top 
contains more protein than palm oil leaves (Table 2). The ratio of NDF:CP for palm oil leaves is 15.44 , while sugarcane-top is only 13.28 , indicated the quality of the feed.

Findings of the study indicated that the effect of tannin more stronger than saponin in reducing the proportion of methane to total gas. The results were coherent with the report of Jayanegara et al. (2012) indicated that tannin has an antimethanogenic effect. Differences in the effect of tannin and saponin for each feed may be due to differences in the chemical composition, in particularly NDF and energy content of the feed. The NDF content has negative corelation with digestibility.

\section{CONCLUSION}

It is concluded that the two agents (condensed tannin and saponin) can reduce the proportion of methane to total gas during the rumen fermentation of feedstuffs. However, the effect of tannin and saponin was different among the feedstuff investigated. Tannin has larger effect on reducing the proportion of methane to total gas than saponin. The largest effect of tannin and saponin was on sugarcane top. Ensiling did not constantly reduce methane production among the feedstuffs investigated.

\section{ACKNOWLEDGEMENT}

The authors thanks to the staffs in the Feed Laboratory and the Methane laboratory at the Indonesian Research Institute for Animal Production (IRIAP) for their help during the experiment undertaken. The fund was provided by the Indonesian Agency for Agricultural Research and Development (IAARD) through the KKP3N program in year 2013 was acknowledged.

\section{REFERENCES}

AOAC. 1990. Official methods of analysis association of official analytical chemists. $16^{\text {th }}$ ed. Washington DC (USA): AOAC International.

Astuti DA, Wina E, Haryanto B, Suharti S. 2008. Peningkatan produksi sapi potong melalui pakan aditif lerak (Sapindus rarak DC) pada pemberian ransum berbasis hijauan tinggi. Laporan Penelitian dan Pengabdian Masyarakat. Bogor (Indonesia): IPB bekerja sama dengan BPT.

Beauchemin AK, McGinn SM. 2005. Methane emissions from feedlot cattle fed barley or corn diets. J Anim Sci. 83:653-661.

Fathoni T. 2010. Pengolahan hasil hutan kayu. Jakarta (Indonesia): RPI.

Hart KJ, Martin PG, Foley PA, Kenny DA, Boland TM. 2009. Effect of sward dry matter digestibility on methane production, ruminal fermentation, and microbial populations of zerograzed beef cattle. J Anim Sci. 87:3342-3350.

Jayanegara A, Wina E, Takahashi J. 2014. Meta-analysis on methane mitigating properties of saponin-rich sources in the rumen: Influence of addition levels and plant sources. Asian Australas J Anim Sci. 27:1426-1435.

Jayanegara A, Leiber F, Kreuzer M. 2012. Meta-analysis of the relationship between dietary tannin level and methane formation in ruminants from in vivo and in vitro experiments. J Anim Physiol Anim Nutr. 96:365-375.

Jayanegara A, Kreuzer M, Wina E, Leiber F. 2011. Significance of phenolic compounds in tropical forages for the ruminal bypass of polyunsaturated fatty acids and the appearance of biohydrogenation intermediates as examined in vitro. Anim Prod Sci. 51:1127-1136. 
Jayanegara A, Goel G, Makkar HPS, Becker K. 2010. Reduction in methane emissions from ruminants by plant secondary metabolites: Effects of polyphenols and saponins. In: Odongo NE, Garcia M, Viljoen GJ, editors. Sustainable improvement of animal production and health. Rome (Italy): FAO. p. 151-157.

Kamra DN, Agarwal N, Chaudhary LC. 2006. Inhibition of ruminal methanogenesis by tropical plants containing secondary compounds. Int Congr Ser. 1293:156-163.

Liang JB, Wang Y, Johromi MF. 2013. Challenges of mitigation green house gases from animal agriculture in third world countries. JIRCAS Working Report. 79:5-8.

Kulivand M, Kafilzadeh F. 2015. Correlation between chemical composition, kinetics of fermentation and methane production of eight pasture grasses. Acta Scientiarum. Anim Sci Maringá. 37:9-14.

Makkar HPS, Blümmel M, Becker K. 1995a. Formation of complexes between polyvinyl pyrrolidone and polyethylene glycol with tannins and their implications in gas production and true digestibility in in vitro techniques. Brit J Nutr. 73:897-913.

Makkar HPS, Blümmel M, Becker K. 1995b. In vitro effects of and interactions between tannins and saponins and fate of tannins in the rumen. J Sci Food Agric. 69:481-493.

Maryono, Krishna NH. 2009. Pemanfaatan dan keterbatasan hasil ikutan pertanian serta strategi pemberian pakan berbasis limbah pertanian untuk sapi potong. Wartazoa 19:31-42.

Pramote P, Liang JB, Jelan ZA, Basery M. 2006. Utilisation of steam-treated oil palm frounds in growing goats: 1. Supplementation with dietary urea. Asian-Australas J Anim Sci. 19:13051313.

Tavendale MH, Meagher LP, Pacheco D, Walker N, Attwood GT, Sivakumaran S. 2005. Methane production from in vitro rumen incubations with Lotus pedunculatus and Medicago sativa, and effects of extractable condensed tannin fractions on methanogenesis. Anim Feed Sci Technol. 123-124:403-419. DOI: http://dx.doi.org/10.1016/j.anifeedsci.2005.04.037

Thalib A. 2008. Isolasi dan identifikasi bakteri asetogenik dari rumen rusa dan potensinya sebagai inhibitor metanogenesis. JITV. 13:197-206.

Thalib A, Widiawati Y, Haryanto B. 2010. Penggunaan complete rumen modifier ("CRM") pada ternak domba yang diberi hijauan pakan berserat tinggi. JITV. 15:97-104.

Thalib A. 2004. Uji efektivitas saponin buah Sapindus rarak sebagai inhibitor metanogenesis secara in vitro pada system pencernaan rumen. JITV. 9:164-171.

Thalib A, Situmorang P, Mathius IW, Widiawati Y, Puastuti W. 2011. The utilization of the complete rumen modifier on dairy cows. J Indonesian Trop Anim Agric. 36:137-142.

Tjandraatmadja M. 1981. Anaerobic digestion of fibrous materials [Thesis]. [Melbourne (AUS)]: University of Melbourne.

Van Soest PJ, Robertson JB, Lewis B.1991. Methods for dietary fiber, neutral detergent fiber, and non-starch polysaccharides in relation to animal nutrition. J Dairy Sci. 74:3583-3597.

Widiawati Y. 2004. The utilisation of tropical shrub legumes: Leucaena leucocephala, Gliricidia sepium and Calliandra callothyrsus by ruminant animals [Dissertation]. [Townsville (AUS)]: James Cook University Towns ville.

Widiawati Y. 2013. Current and future mitigaion activities on methane emission from ruminant in Indonesia. In: International Workshop on Inventory Data and Mitigation of Carbon and Nitrogen Cycling from Livestock in Indonesia. Jakarta, 24 April 2013.

Yogianto, Sudarman A, Wina E, Jayanegara A. 2014. Supplementation effects of tannin and saponin extracts to diets with different forage to concentrate ratio on in vitro rumen fermentation and methanogenesis. J Indonesian Trop Anim Agric. 39:144-151. 